Bangladesh J. Sci. Ind. Res. 41(3-4), 227-234, 2006

\title{
Spirulina Culture in Bangladesh XI \\ Selection of a Culture Medium, Suitable for Culturing a Local Strain of Spirulina
}

\author{
R. Khatun, P. Noor, N. Akhter, M. A. A. Jahan, M. Hossain and J. L. Munshi \\ Biological Research Division, BCSIR Laboratories, Dhaka, Bangladesh
}

\begin{abstract}
Large scale Spirulina culture is possible in Bangladesh inspite of unpredictable climatic condition. Effect of different culture media on the growth of a local strain of Spirulina (Spirulina platensis) was studied. Bangladesh medium $\left(\mathrm{Bd}_{1}\right)$ was found to be more favourable for the growth of the alga. All together three culture media were included in this study.
\end{abstract}

\section{Introduction}

Spirulina is a microscopic unbranched, filamentous blue-green alga, rich in protein, vitamins especially vitamin $B_{12}$ and pro-vitamin A (beta-carotene), iron, essential amino acids, minerals and essential fatty acids like gamma linolenic acid (GLA).

Spirulina has a long history of use as food. There are reports that Spirulina was used traditionally by Mexicans during Aztec civilization for over 1000 years. Its use as a food by the natives in the lake Chad area has also been documented by the French phycologist Dangeard. Its safety for human food has since been established through various toxicological studies sponsored by the United Nations Industrial Development Organization (UNIDO).
It is found as an unialgal culture in some alkaline lakes with a very high $\mathrm{pH}$, sometimes reaching 11 . Such a $\mathrm{pH}$ prohibits the growth of most other algae. Now it is produced commercially and sold as a food supplement in health stores around the world. Up to very recently, the interest in Spirulina was mainly in its nutritive value. Currently, some people are looking into the possible therapeutic effects of Spirulina. Pre-clinical and clinical studies suggest several therapeutic effects of Spirulina ranging from reduction of cholesterol and cancer to enhancing the immune system, increasing intestinal lactobacillus, reducing nephrotoxicity, heavy metals and drugs and radiation protection. ${ }^{1}$ 
Spirulina is available in ditches, ponds, lake etc. in Bangladesh in combination with other algae. A local strain of Spirulina in pure form was collected from a pond near the airport road, Uttara, Dhaka. Several culture media were reported to be used by various authors for Spirulina culture. $^{2-4}$ In Biolo-gical Research Division, BCSIR Labs., Dhaka, Spirulina was cultured at pilot plant scale for over 12 years. ${ }^{5-7}$ Bangladesh medium I $\left(\mathrm{Bd}_{1}\right)$ was developed in our laboratory for commercial production of Spirulina in Bangladesh. ${ }^{8}$ Another medium was developed in the same Laboratory for domestic scale culture of Spirulina in Bangladesh. ${ }^{9}$ The present study was undertaken with a view to select a culture medium suitable for culturing the local strain of Spirulina.

\section{Materials and Methods}

The study was conducted using a local strain of Spirulina, collected from a pond near Airport Road, Uttara, Dhaka. Three media were included in this study, $\mathrm{Bd}_{1}, \mathrm{Bd}_{4}$ and IFP. $\mathrm{Bd}_{1}$ medium was also used in the control sets of this study. It is used for Spirulina production in the pilot plant ponds at BCSIR. The commercial strain of Spirulina was used in the control sets. For the preliminary trial, 20 flasks of 1 litre capacity were used. Graduated pipettes were used to dispose the inocula and graduated measuring cylinders were used for adding $400 \mathrm{ml}$. of different cul- ture media to each set, consisting of 5 flasks. These were inoculated with $20 \mathrm{ml}$ of Spirulina (local strain, commercial strain in control only). The culture flasks were kept in the southern veranda in day time but at night these were exposed to total darkness. The optical density (OD) of the culture was recorded by a Spectrophotometer for maintenance of the growth record. $\mathrm{pH}$ of the culture was recorded by a $\mathrm{pH}$ meter. Temperature of the culture was recorded by a centigrade thermometer. The condition of Spirulina culture was observed under a compound microscope (X 80), once a week. The experiment was conducted for one month. After that the cultures were transferred to plastic bowls of 20 litres capacity (3 bowls in each set), for continuation of the comparative study at larger scale. This experiment was conducted for two months. Temperature, $\mathrm{pH}$, optical density (OD) and microscopic observations were recorded twice a month. On the basis of this study, a medium was selected $\left(\mathrm{Bd}_{1}\right)$. After that, the local strain of Spirulina was cultured in $\mathrm{Bd}_{1}$ medium in a cement basin (174 cm X $24 \mathrm{~cm}$ ) for six months. Finally the Spirulina culture was transferred to a cement pond ( 2 sq. meter) for growth study at a pilot plant scale for one year.

\section{Results and Discussion}

Results of the study are presented in Tables I to IV. 
The following culture media were used in this study

\begin{tabular}{lccc}
\hline Particulars & Medium No. $1 \mathrm{Bd}_{1}$ & Medium No. $2 \mathrm{Bd}_{4}$ & Medium No. 3 IFP \\
\hline $\mathrm{NaHCO}_{3}$ & $3.2 \mathrm{~g}$. & $4 \mathrm{~g}$. & $16.8 \mathrm{~g}$. \\
$\mathrm{NaNO}_{3}$ & $0.5 \mathrm{~g}$. & & $2.5 \mathrm{~g}$. \\
$\mathrm{KCl}$ & $0.2 \mathrm{~g}$. & & $1.0 \mathrm{~g}$. \\
$\mathrm{MgSO}_{4}, 2 \mathrm{H}_{2} \mathrm{O}$ & $0.1 \mathrm{~g}$. & & $0.5 \mathrm{~g}$. \\
$\mathrm{CaCl}_{2}$ & $0.008 \mathrm{~g}$. & $0.04 \mathrm{~g}$ \\
$\mathrm{FeSO}_{4}, 7 \mathrm{H}_{2} \mathrm{O}$ & $0.002 \mathrm{~g}$. & & $0.01 \mathrm{~g}$. \\
$\mathrm{H}_{2} \mathrm{SO}_{4}(96 \%)$ & $0.1 \mathrm{ml}$. & & $0.5 \mathrm{ml}$. \\
$\mathrm{H}_{3} \mathrm{PO}_{4}(85 \%)$ & $0.4 \mathrm{ml}$. & & $0.2 \mathrm{ml}$. \\
$\mathrm{EDTA}$ & $0.008 \mathrm{~g}$. & $4.0 \mathrm{~g}$. & $0.04 \mathrm{~g}$. \\
$\mathrm{NaCl}_{\text {Urea }}$ & & $2.5 \mathrm{~g}$. & \\
Water & & $1000 \mathrm{ml}$. & $1000 \mathrm{ml}$. \\
pH & $1000 \mathrm{ml}$. & 8.3 & 8.8 \\
\hline
\end{tabular}

Effect of three different culture media on a local strain of Spirulina is presented in Table I.

Among seven different culture media, used by different authors for Spirulina culture three were included in this study. ${ }^{2-4,8-9}$ In the preliminary comparative study, a local strain of Spirulina was cultured in three different media $\left(\mathrm{Bd}_{1}, \mathrm{Bd}_{4}\right.$ and IFP) for one month. A commercial strain of Spirulina, cultured in $\mathrm{Bd}_{1}$ medium, was used as control. Initially growth of the local strain was equally good in all the three media $\left(\mathrm{Bd}_{1}, \mathrm{Bd}_{4}\right.$ and IFP). However, after one month, condition and colour of local strain of Spirulina was better in $\mathrm{Bd}_{1}$ than $\mathrm{Bd}_{4}$ and IFP media (Table I). Contamination was very few.

In continuation of the study, the local strain of Spirulina and the control were cultured in plastic bowls, in the above media for another two months. Results of the study are presented in Table II.

In this study, the local strain of Spirulina showed better response to $\mathrm{Bd}_{1}$ medium in comparison to the others, $\mathrm{Bd}_{4}$ and IFP.

To ensure the growth of the local strain of Spirulina in $\mathrm{Bd}_{1}$ medium, the culture was continued in larger scale for six months.

Spirulina was harvested once a month. Feed back was added to the medium after each harvest. Results of the study are presented in Table III.

During the six months trial, the local strain of Spirulina were successfully grown in $\mathrm{Bd}_{1}$ medium. 
Table I. Effect of three different culture media on a local strain of Spirulina, grown in conical flask, for one month.

\begin{tabular}{|c|c|c|c|c|c|c|}
\hline Date & $\begin{array}{l}\text { Culture } \\
\text { medium }\end{array}$ & \begin{tabular}{|c|} 
Temp. \\
${ }^{\circ} \mathrm{C}$
\end{tabular} & $\mathrm{pH}$ & $\begin{array}{c}\text { Optical } \\
\text { density (OD) }\end{array}$ & Condition of Spirulina & Contamination \\
\hline \multirow{4}{*}{$30-06-02$} & $\mathrm{Bd}_{1}$ & $29^{\mathrm{O}} \mathrm{C}$ & 8.7 & 0.33 & $\begin{array}{l}\text { Filaments very good and } \\
\text { healthy, light blue-green }\end{array}$ & $\begin{array}{l}\text { No contami- } \\
\text { nation }\end{array}$ \\
\hline & $\mathrm{Bd}_{4}$ & $29^{\mathrm{O}} \mathrm{C}$ & 8.4 & 0.33 & $\begin{array}{l}\text { Filaments very good and } \\
\text { healthy, light blue-green }\end{array}$ & $\begin{array}{l}\text { No contami- } \\
\text { nation }\end{array}$ \\
\hline & IFP & $29^{\mathrm{O}} \mathrm{C}$ & 8.9 & 0.32 & $\begin{array}{l}\text { Filaments very good and } \\
\text { healthy, light blue-green }\end{array}$ & $\begin{array}{l}\text { No contami- } \\
\text { nation }\end{array}$ \\
\hline & Control & $29^{\mathrm{O}} \mathrm{C}$ & 8.7 & 0.31 & $\begin{array}{l}\text { Filaments very good and } \\
\text { healthy, light blue-green }\end{array}$ & $\begin{array}{l}\text { No contami- } \\
\text { nation }\end{array}$ \\
\hline \multirow{4}{*}{$06-07-02$} & $\mathrm{Bd}_{1}$ & $29^{\mathrm{O}} \mathrm{C}$ & 9.26 & 0.31 & $\begin{array}{l}\text { Filaments very good and } \\
\text { healthy, light blue-green }\end{array}$ & $\begin{array}{l}\text { Paramecium } \\
\text { very few }\end{array}$ \\
\hline & $\mathrm{Bd}_{4}$ & $29^{\mathrm{O}} \mathrm{C}$ & 8.96 & 0.18 & $\begin{array}{c}\text { Filaments in broken } \\
\text { condition, light blue-green }\end{array}$ & $\begin{array}{l}\text { No contami- } \\
\text { nation }\end{array}$ \\
\hline & IFP & $29^{\circ} \mathrm{C}$ & 9.26 & 0.26 & $\begin{array}{l}\text { Some filaments in good } \\
\text { condition, some in broken } \\
\text { condition, light blue-green }\end{array}$ & $\begin{array}{l}\text { Paramecium } \\
\text { very few }\end{array}$ \\
\hline & Control & $29^{\circ} \mathrm{C}$ & 9.14 & 0.20 & $\begin{array}{l}\text { Filaments in very good } \\
\text { condition, light blue-green }\end{array}$ & $\begin{array}{l}\text { Zooplankton } \\
\text { very few }\end{array}$ \\
\hline \multirow{4}{*}{$12-07-02$} & $\mathrm{Bd}_{1}$ & $30^{\circ} \mathrm{C}$ & 8.90 & 0.13 & $\begin{array}{l}\text { Filaments very good and } \\
\text { healthy, light blue-green }\end{array}$ & $\begin{array}{l}\text { Paramecium } \\
\text { very few }\end{array}$ \\
\hline & $\mathrm{Bd}_{4}$ & $30^{\circ} \mathrm{C}$ & 8.58 & 0.11 & $\begin{array}{l}\text { Filaments broken into small } \\
\text { pieces, very light blue-green }\end{array}$ & $\begin{array}{l}\text { No contami- } \\
\text { nation }\end{array}$ \\
\hline & IFP & $30^{\circ} \mathrm{C}$ & 9.10 & 0.25 & $\begin{array}{c}\text { Filaments good and healthy, } \\
\text { blue-green }\end{array}$ & $\begin{array}{l}\text { No contami- } \\
\text { nation }\end{array}$ \\
\hline & Control & $30^{\circ} \mathrm{C}$ & 8.86 & 0.17 & $\begin{array}{c}\text { Filaments good and healthy, } \\
\text { blue-green }\end{array}$ & $\begin{array}{l}\text { Paramecium } \\
\text { and Phacus } \\
\text { very few }\end{array}$ \\
\hline \multirow{4}{*}{$18-07-02$} & $\mathrm{Bd}_{1}$ & $28^{\mathrm{O}} \mathrm{C}$ & 8.25 & 0.64 & $\begin{array}{c}\text { Filaments very good and } \\
\text { healthy, blue-green }\end{array}$ & $\begin{array}{l}\text { No contami- } \\
\text { nation }\end{array}$ \\
\hline & $\mathrm{Bd}_{4}$ & $28^{\mathrm{O}} \mathrm{C}$ & 8.20 & 0.65 & $\begin{array}{l}\text { Filaments good and healthy, } \\
\text { light blue-green. }\end{array}$ & $\begin{array}{l}\text { No contami- } \\
\text { nation }\end{array}$ \\
\hline & IFP & $28^{\mathrm{O}} \mathrm{C}$ & 8.20 & 0.58 & $\begin{array}{l}\text { Filaments good and healthy, } \\
\text { blue-green }\end{array}$ & $\begin{array}{l}\text { No contami- } \\
\text { nation }\end{array}$ \\
\hline & Control & $28^{\mathrm{O}} \mathrm{C}$ & 8.50 & 1.01 & $\begin{array}{l}\text { Filaments good and healthy, } \\
\text { light blue-green }\end{array}$ & $\begin{array}{l}\text { No contami- } \\
\text { nation }\end{array}$ \\
\hline
\end{tabular}


Table I. continued

\begin{tabular}{|c|c|c|c|c|c|c|}
\hline Date & $\begin{array}{l}\text { Culture } \\
\text { medium }\end{array}$ & $\begin{array}{l}\text { Temp. } \\
{ }^{\circ} \mathrm{C}\end{array}$ & $\mathrm{pH}$ & $\begin{array}{c}\text { Optical } \\
\text { density (OD) }\end{array}$ & Condition of Spirulina & Contamination \\
\hline \multirow{4}{*}{ 24-07-02 } & $\mathrm{Bd}_{1}$ & $27^{\mathrm{O}} \mathrm{C}$ & 9.30 & 0.28 & $\begin{array}{l}\text { Filaments very good and } \\
\text { healthy, a few filaments in bro- } \\
\text { ken condition, blue-green }\end{array}$ & $\begin{array}{l}\text { Paramecium } \\
\text { very few }\end{array}$ \\
\hline & $\mathrm{Bd}_{4}$ & $27^{\mathrm{O}} \mathrm{C}$ & 9.22 & 0.26 & $\begin{array}{l}\text { Most of the filaments broken } \\
\text { into pieces, light blue-green. }\end{array}$ & $\begin{array}{l}\text { No conta- } \\
\text { mination }\end{array}$ \\
\hline & IFP & $27^{\mathrm{O}} \mathrm{C}$ & 9.50 & 0.32 & $\begin{array}{l}50 \% \text { of the filaments in broken } \\
\text { condition, light blue-green }\end{array}$ & $\begin{array}{l}\text { No conta- } \\
\text { mination }\end{array}$ \\
\hline & Control & $27^{\mathrm{O}} \mathrm{C}$ & 9.28 & 0.81 & $\begin{array}{c}\text { Filaments in good condition., a } \\
\text { few in broken condition, } \\
\text { blue-green }\end{array}$ & $\begin{array}{c}\text { Protozoa a } \\
\text { few }\end{array}$ \\
\hline \multirow{4}{*}{ 30-07-02 } & $\mathrm{Bd}_{1}$ & $28^{\mathrm{O}} \mathrm{C}$ & 9.46 & 0.34 & $\begin{array}{l}\text { Filaments good and healthy, } \\
\text { blue-green }\end{array}$ & $\begin{array}{l}\text { No conta- } \\
\text { mination }\end{array}$ \\
\hline & $\mathrm{Bd}_{4}$ & $28^{\mathrm{O}} \mathrm{C}$ & -- & -- & All filaments destroyed, brown & $\begin{array}{l}\text { No conta- } \\
\text { mination }\end{array}$ \\
\hline & IFP & $28^{\mathrm{O}} \mathrm{C}$ & 9.75 & 0.09 & $\begin{array}{l}\text { Most of the filaments in good } \\
\text { condition, blue-green }\end{array}$ & $\begin{array}{l}\text { No conta- } \\
\text { mination }\end{array}$ \\
\hline & Control & $28^{\mathrm{O}} \mathrm{C}$ & 9.60 & 0.36 & $\begin{array}{c}\text { Filaments in good condition, } \\
\text { light blue-green }\end{array}$ & $\begin{array}{l}\text { No conta- } \\
\text { mination }\end{array}$ \\
\hline
\end{tabular}

* Average of 5 flasks

Table II. Effect of three different culture media on a local strain of Spirulina, grown in plastic bowls for two months.

\begin{tabular}{c|c|c|c|c|c|c}
\hline \multirow{2}{*}{ Date } & $\begin{array}{c}\text { Culture } \\
\text { medium }\end{array}$ & $\begin{array}{c}\text { Temp. } \\
\mathrm{O} \mathrm{C}\end{array}$ & $\mathrm{pH}$ & $\begin{array}{c}\text { Optical } \\
\text { density (OD) }\end{array}$ & Condition of Spirulina & $\begin{array}{c}\text { Contami- } \\
\text { nation }\end{array}$ \\
\hline \multirow{2}{*}{$01-08-02$} & $\mathrm{Bd}_{1}$ & $26^{\mathrm{O}} \mathrm{C}$ & 9.5 & 0.60 & $\begin{array}{c}\text { Very good and healthy, } \\
\text { blue-green colour }\end{array}$ & Nil \\
\cline { 2 - 7 } & $\mathrm{Bd}_{4}$ & $26^{\mathrm{O}} \mathrm{C}$ & 9.4 & 0.60 & $\begin{array}{c}\text { Very good and healthy, } \\
\text { blue-green colour }\end{array}$ & Nil \\
\cline { 2 - 7 } & $\mathrm{IFP}$ & $26^{\mathrm{O}} \mathrm{C}$ & 9.4 & 0.60 & $\begin{array}{c}\text { Very good and healthy, } \\
\text { blue-green colour }\end{array}$ & Nil \\
\cline { 2 - 7 } & Control & $26^{\mathrm{O}} \mathrm{C}$ & 9.5 & 0.60 & $\begin{array}{c}\text { Very good and healthy, } \\
\text { blue-green colour }\end{array}$ & Nil \\
\hline
\end{tabular}


Table II. continued

\begin{tabular}{|c|c|c|c|c|c|c|}
\hline Date & \begin{tabular}{|l|} 
Culture \\
medium \\
\end{tabular} & $\begin{array}{c}\text { Temp. } \\
{ }^{\mathrm{O}} \mathrm{C}\end{array}$ & $\mathrm{pH}$ & $\begin{array}{c}\text { Optical } \\
\text { density (OD) }\end{array}$ & Condition of Spirulina & $\begin{array}{c}\text { Contami- } \\
\text { nation }\end{array}$ \\
\hline \multirow{4}{*}{$17-08-02$} & $\mathrm{Bd}_{1}$ & $25^{\mathrm{O}} \mathrm{C}$ & 9.5 & 0.78 & $\begin{array}{l}\text { Very good and healthy, } \\
\text { blue-green colour }\end{array}$ & Nil \\
\hline & $\mathrm{Bd}_{4}$ & $25^{\mathrm{O}} \mathrm{C}$ & 9.1 & 0.65 & $\begin{array}{c}\text { Good, a few filaments in broken con- } \\
\text { dition, light blue-green colour }\end{array}$ & Low \\
\hline & IFP & $25^{\mathrm{O}} \mathrm{C}$ & 9.4 & 0.70 & $\begin{array}{l}\text { Very good and healthy, } \\
\text { blue-green colour }\end{array}$ & Low \\
\hline & Control & $25^{\mathrm{O}} \mathrm{C}$ & 9.5 & 0.75 & $\begin{array}{l}\text { Very good and healthy, } \\
\text { blue-green colour }\end{array}$ & Nil \\
\hline \multirow{4}{*}{$31-08-02$} & $\mathrm{Bd}_{1}$ & $30^{\circ} \mathrm{C}$ & 9.4 & 0.85 & $\begin{array}{l}\text { Very good and healthy, } \\
\text { blue-green colour }\end{array}$ & Low \\
\hline & $\mathrm{Bd}_{4}$ & $26^{\mathrm{O}} \mathrm{C}$ & 9.0 & 0.68 & $\begin{array}{l}\text { Good, a few filaments in broken } \\
\text { condition, light blue-green colour }\end{array}$ & Low \\
\hline & IFP & $26^{\mathrm{O}} \mathrm{C}$ & 9.3 & 0.77 & Good and healthy, blue-green colour & Low \\
\hline & Control & $26^{\mathrm{O}} \mathrm{C}$ & 9.5 & 0.80 & $\begin{array}{l}\text { Very good and healthy, } \\
\text { blue-green colour }\end{array}$ & Low \\
\hline \multirow{4}{*}{$15-09-02$} & $\mathrm{Bd}_{1}$ & $26^{\mathrm{O}} \mathrm{C}$ & 9.5 & 1.00 & $\begin{array}{l}\text { Very good and healthy, } \\
\text { blue-green colour }\end{array}$ & Nil \\
\hline & $\mathrm{Bd}_{4}$ & $26^{\mathrm{O}} \mathrm{C}$ & 9.2 & 0.70 & $\begin{array}{l}\text { Filaments in broken condition, } \\
\text { light blue-green colour }\end{array}$ & Low \\
\hline & IFP & $26^{\mathrm{O}} \mathrm{C}$ & 9.4 & 0.80 & $\begin{array}{l}\text { Good, a few filaments in broken } \\
\text { condition, light blue-green colour }\end{array}$ & Nil \\
\hline & Control & $26^{\mathrm{O}} \mathrm{C}$ & 9.7 & 0.90 & Good and healthy, blue-green colour & Nil \\
\hline \multirow{4}{*}{$30-09-02$} & $\mathrm{Bd}_{1}$ & $26^{\mathrm{O}} \mathrm{C}$ & 9.3 & 1.00 & $\begin{array}{l}\text { Very good and healthy, } \\
\text { blue-green colour }\end{array}$ & Nil \\
\hline & $\mathrm{Bd}_{4}$ & $26^{\mathrm{O}} \mathrm{C}$ & 9.2 & 0.70 & $\begin{array}{c}\text { Filaments in broken condition, } \\
\text { light blue-green colour }\end{array}$ & Nil \\
\hline & IFP & $26^{\mathrm{O}} \mathrm{C}$ & 9.3 & 0.82 & $\begin{array}{l}\text { Good, a few filaments in broken } \\
\text { condition, light blue-green colour }\end{array}$ & Nil \\
\hline & Control & $26^{\mathrm{O}} \mathrm{C}$ & 9.4 & 0.95 & Good and healthy, blue-green colour & Nil \\
\hline
\end{tabular}

* Average of 3 bowls 
Table III. Effect of $\mathbf{B d}_{1}$ medium on the growth of local strain of Spirulina in cement basin, for six months

\begin{tabular}{c|c|c|c|c|c}
\hline Date & $\begin{array}{c}\text { Temp. } \\
\text { O } \mathrm{C}\end{array}$ & pH & $\begin{array}{c}\text { Optical } \\
\text { density (OD) }\end{array}$ & Condition of Spirulina & $\begin{array}{c}\text { Yield of } \\
\text { Spirulina (dry } \\
\text { wt. in g.) }\end{array}$ \\
\hline $01-10-02$ & $26^{\mathrm{O}} \mathrm{C}$ & 9.3 & 0.57 & Very good and healthy, blue-green colour & - \\
$01-11-02$ & $25^{\mathrm{O}} \mathrm{C}$ & 9.0 & 0.50 & Very good and healthy, blue-green colour & 13.5 \\
$02-12-02$ & $21^{\mathrm{O}} \mathrm{C}$ & 7.0 & 0.65 & Good and healthy, light blue-green colour & 18.5 \\
$01-01-03$ & $18^{\mathrm{O}} \mathrm{C}$ & 10 & 0.70 & Good and healthy, light blue-green colour & 11.0 \\
$01-02-03$ & $19^{\mathrm{O}} \mathrm{C}$ & 9.1 & 0.75 & Very good and healthy, blue-green colour & 16.0 \\
$01-03-03$ & $20^{\mathrm{O}} \mathrm{C}$ & 9.0 & 1.00 & Very good and healthy, blue-green colour & 30.0 \\
\hline
\end{tabular}

In a further extensive study, the local strain was cultured in $\mathrm{Bd}_{1}$ medium at a larger scale for one whole year (pilot plant pond).
The Spirulina was harvested once a month and feed back was added in the culture medium after each harvest. Data representing the

Table IV. Effect of $\mathrm{Bd}_{1}$ medium on the local strain of Spirulina, grown in pilot pond for one year

\begin{tabular}{|c|c|c|c|c|c|}
\hline Date & $\begin{array}{c}\text { Temp. } \\
{ }^{\circ} \mathrm{C}\end{array}$ & $\mathrm{pH}$ & \begin{tabular}{|c|} 
Optical \\
density (OD)
\end{tabular} & Condition of Spirulina & $\begin{array}{l}\text { Yield of } \\
\text { Spirulina (dry } \\
\text { wt. in g.) }\end{array}$ \\
\hline $02-03-03$ & $20^{\circ} \mathrm{C}$ & 9.5 & 0.60 & Very good and healthy, blue-green colour & -- \\
\hline 02-04-03 & $20^{\circ} \mathrm{C}$ & 10 & 0.85 & Very good and healthy, blue-green colour & 17.0 \\
\hline 02-05-03 & $28^{\mathrm{O}} \mathrm{C}$ & 10 & 1.0 & $\begin{array}{l}\text { Good and healthy, blue-green colour, very } \\
\text { few zooplankton present }\end{array}$ & 43.0 \\
\hline 02-06-03 & $29^{\mathrm{O}} \mathrm{C}$ & 10 & 0.9 & Good and healthy, blue-green colour & 31.2 \\
\hline 02-07-03 & $26^{\mathrm{O}} \mathrm{C}$ & 10 & 0.75 & $\begin{array}{c}\text { Good and healthy, blue-green colour, } \\
\text { a few protozoa present }\end{array}$ & 16.5 \\
\hline 02-08-03 & $28^{\mathrm{O}} \mathrm{C}$ & 9.0 & 0.85 & Good and healthy, blue-green colour & 30.0 \\
\hline 02-09-03 & $31^{\mathrm{O}} \mathrm{C}$ & 9.0 & 1.0 & Very good and healthy, blue-green colour & 41.5 \\
\hline $02-10-03$ & $23^{\mathrm{O}} \mathrm{C}$ & 9.1 & 0.90 & Good and healthy, blue-green colour & 30.5 \\
\hline 02-11-03 & $29^{\circ} \mathrm{C}$ & 9.2 & 0.65 & $\begin{array}{l}\text { Good and healthy, blue-green colour, very } \\
\text { few zooplankton present }\end{array}$ & 18.5 \\
\hline $02-12-03$ & $23^{\mathrm{O}} \mathrm{C}$ & 9.3 & 0.55 & Good and healthy, blue-green colour & 7.5 \\
\hline 02-01-04 & $20^{\circ} \mathrm{C}$ & 9.5 & 0.60 & Good and healthy, blue-green colour & 11.5 \\
\hline 02-02-04 & $21^{\mathrm{O}} \mathrm{C}$ & 9.8 & 0.65 & Good and healthy, blue-green colour & 30.5 \\
\hline
\end{tabular}


growth of Spirulina during the year are presented in Table IV.

Table IV reveals the fact that, the local Spirulina strain, included in this study, grew well in $\mathrm{Bd}_{1}$ medium all throughout the year. The growth did not totally stop in any month during the study. $\mathrm{Bd}_{1}$ medium supported good growth of local strain of Spirulina, retaining its normal blue-green colour.

\section{Conclusion}

The local strain of Spirulina (Spirulina platensis) included in this study was found to be suitable for culturing all throughout the year in $\mathrm{Bd}_{1}$ medium in Bangladesh.

\section{Acknowledgement}

The authors are indebted to Dr. F.Z. Majid, Ex-Chairman, BCSIR for her encouragement during the study. Grateful acknowledgement is also due to the Director, Dhaka Laboratories, for his kind help during the study.

\section{References}

1. A. Belay, Y. Ota, K. Miyakawa and H. Shimamatsu. Current knowledge on potential health benefits of Spirulina, Journal of Applied Phycology, 5 (1993) 235-241.

2. L. V. Venkataraman and E. W. Becker. Biotechnology and utilization of algae. The Indian Experiences D.S.T., New Delhi, India and C.F.T.R.I., Mysore, India, (1982).

3. R. D. Fox. Algoculture. Doctorate Thesis, Lois Pasteur Strosbourg, France, (1983).
4. G. Bonnin, B.E.C.C.M.A., Spirulina Production Engineering Handbook, B.E.C. C.M.A., France, (1992).

5. L. Nahar, S. Begum, R. Khatun and M. Hossain. Spirulina Culture in Bangladesh I. A pilot plant scale study on the growth of Spirulina platensis and Spirulina fusiformis, BJSIR, 29(1) (1994) 84-95.

6. P. Noor, M. A. A. Jahan, N. Akhter and F. Z. Majid. Spirulina Culture in Bangladesh II. Control of natural contaminants, BJSIR 29(1) (1994) 96-109.

7. F. Z. Majid. A report on Spirulina culture in Bangladesh. Past, present and future, Spirulina Etra National Symposium, M.C.R.C., Madras, India, (1991).

8. M. A. A. Jahan, P. Noor, N. Akhter and L. Nahar. Spirulina Culture in Bangladesh III. Development of a medium suitable for commercial cultivation of Spirulina in Bangladesh. BJSIR, 29(4) (1994), 147-150.

9. S. Begum, P. Noor, N. Akhter and F. Z. Majid. Spirulina Culture in Bangladesh VI. Domestic scale production of Spirulina. BJSIR 29(3) (1998) 473-478.

10. R. Khatun and F. Z. Majid. A Report on Spirulina Culture in Bangladesh - Past, Present and Future. BCSIR Laboratories, Dhaka, 2005. 
